\title{
Clinicopathological analysis and surgical approach of ovarian fibroma/fibrothecoma with 51 cases
}

\section{Opere edilen 51 fibrom/fibrotekom vakasının klinikopatolojik bulgularının değerlendirilmesi}

\author{
Ferah KAZANCI ${ }^{1}$ (D), Mehmet Arda INAN ${ }^{2}$ (D), Özlem ERDEM $^{2}$ (D) Mehmet Anıl ONAN ${ }^{1}$, \\ Neslihan YEREBASMAZ
}

${ }^{1}$ Gazi University, Faculty of Medicine, Department of Gynecological Oncology, 06500, Ankara-Turkey

${ }^{2}$ Gazi University, Faculty of Medicine, Department of Surgical Pathology, 06500, Ankara-Turkey

${ }^{3}$ Yüksek Ihtisas University Faculty of Medicine Obstetrics and Gynecology, 06680, Ankara-Turkey

Atıf gösterme/Cite this article as: Kazancı F, İnan MA, Erdem Ö, Onan MA, Yerebasmaz N. Clinicopathological analysis and surgical approach of ovarian fibroma/fibrothecoma with 51 cases. ADYÜ Săgllk Bilimleri Derg. 2021;7(3):176-182. doi:10.30569.adiyamansaglik.877746

\begin{abstract}
Aim: Ovarian fibroma, fibrothecoma and thecoma are benign neoplasia of the ovary. The aim of this study is to analyze the clinical characteristics, histopathological results and surgical management of ovarian fibroma/fibrothecoma.

Materials and Methods: This is a retrospective study of 51 cases who underwent surgical treatment because of adnexial mass. The cases reported as ovarian fibroma/fibrothecomas were analyzed.

Results: The mean age of patients were 58.7 years old. The avarage diameter of tumours was $8.23 \mathrm{~cm}$. The final pathological results were fibroma, fibrothecoma, celluler mitotic fibroma, respectively $45.2 \%, 35.3 \%$, $13.7 \%$. Ascite was viewed in $6(11.7 \%)$ cases. Ca-125 levels were high in 12 cases $(23.5 \%) .11(21.6 \%)$ patients underwent laparoscopy and 40 (78.4\%) underwent laparotomy.

Conclusion: Ovarian fibroma/fibrothecomas are rarely, benign solid tumors. They can be mistaken as myoma or malignancy because of the apperance of tumor with high level Ca-125. These tumors can be treated succesfully by laparoscopy or laparotomy.
\end{abstract}

Keywords: Gynecologic oncology; Ovarian fibroma; Fibrothecoma.
Öz

Amaç: Over kaynaklı fibrom/fibrotekomlar benign neoplazmlardır. Bu çalışmada amacımız opere edilen fibrom/fibrotekom vakalarının klinik bulguları, demografik özellikleri, cerrahi yaklaşımları ve histopatolojik sonuçlarıyla değerlendirmektir.

Gereç ve Yöntem: $\mathrm{Bu}$ retrospektif çalışmada adneksiyel kitle ön tanısı ile opere edilen ve patoloji sonucu fibrom/fibrotekom olan 51 vaka analiz edildi.

Bulgular: Hastaların yaş ortalaması 58,7 , tümör çap1 ortalama $8,23 \mathrm{~cm}$ idi. Nihai patoloji sonuçlarında fibrom, fibrotekom, seluler mitotik fibrom oranları sırasıly $\% 45, \% 35, \% 13,7$ idi. Vakaların $6(\% 11,7)$ inde asit izlendi. Ca-125 seviyesi $12(\% 23,5)$ vakada yüksek saptand. $11(\% 21,6)$ vakaya laparoskopi, $40(\% 78,4)$ vakaya laparotomi yapıldı.

Sonuç: Over kaynaklı fibrom/fibrotekomlar nadir, benign solid tümörlerdir. Solid olmasından dolayı myomlarla ve bazende $\mathrm{Ca}-125$ yüksekliği ile seyrettiğinden malignensilerle karışabilirler. Hastalar laparoskopi veya laparotomi ile başarılı olarak tedavi edilirler.

Anahtar Kelimeler: Jinekolojik onkoloji; Ovarian fibroma; Fibrotekoma.

Yazışma Adresi/Address for Correspondence: Neslihan YEREBASMAZ, Yüksek Ihtisas University Faculty of Medicine Obstetrics and Gynecology, 06680, Ankara-Turkey, E-mail: neslihanyerebasmaz@hotmail.com

Geliş Tarihi/Received:23.03.2021 Kabul Tarihi/Accepted:17.08.2021

Yayım Tarihi/Published online:31.12.2021

Bu eser, Creative Commons Atıf-GayriTicari 4.0 Uluslararası Lisansı ile lisanslanmıştır. Telif Hakk1 @ 2021 Adıyaman Üniversitesi Rektörlüğü 


\section{Introduction}

Ovarian fibromas/fibrothecomas are benign neoplasms which belong to sex cord stromal tumors, and constitute 1.0 to $4.0 \%$ of all ovarian tumors. ${ }^{1}, 2$ Although the average time of diagnosis is in postmenopausal period they may be seen in any of age group. ${ }^{3},{ }^{4}$ Usually they are detected in unilateral form and diameter of these tumors may differ from microscopic to remarkably large ones. Frequently, 3 pathologic subtypes (fibroma, thecoma, and fibrothecoma) are determined depending on the distribution of fiber and theca ingredients. The fibromas consist of variable ratio of spindle cells, while thecoma consists of stromal cells which seem like the perifollicular thecal cells. ${ }^{5}$ Certain diagnosis is very difficult preoperatively, and they are usually misdiagnosed as uterine myoma due to the similar solid nature of the two formation on clinical and ultrasound examination. In addition, diagnosis of fibromas can be mistaken with ovarian malignancy because of the the solid of the tumor on ultrasound, the simultaneous coexistence of ascites, pleural effusions and elevated serum Ca-125 levels. ${ }^{6}, 7$ Approximately $15 \%$ of cases have ascites and $<1 \%$ cases are detected with ascites and hydrothorax, termed as Meigs syndromes. ${ }^{8}, 9$ There is no described specific tumor biomarker for fibromas, except for rarely increase in serum Ca-125 level. ${ }^{8}$ Treatment approach for fibromas is surgical removal of tumor followed by evaluation of intraoperative frozen section. Although total abdominal hysterectomy and bilateral salpingooophorectomy is an optional treatment for the cases who have completed their family and postmenopausal women, fertility preserving surgery only with unilateral salpingo-oophorectomy can be a choice for young patients. ${ }^{2}$ Recently, with the advance improvement in minimal-invasive surgery, the laparoscopic approach is favorable to remove tumor from small to moderate size. ${ }^{9-11}$ In this study the clinico-pathological characteristics and the surgical management of all ovarian fibroma/fibrothecoma patients treated at a tertiary care center were evaluated.

\section{Materials and Methods}

The type of the research
This research was a retrospective study, which was conducted in the Department of Obstetrics and Gynecology of Gazi University in Ankara.

\section{The samples of the research}

51 patients operated with the diagnosis of adnexal mass between August 2008 and December 2018 whose final pathological reports were fibroma or fibrothecoma were analyzed.

\section{Treatment protocol}

The demographic characteristics including age, gravida and parity, menopausal status, presenting symptoms, tumor size, lateralization, preoperative tumor markers, surgical procedures and the presence of different pathological findings (endometrioma, fibroid, serous cyst, malignancy) rates were analyzed in this study. Ultrasound investigation was performed for the presence and estimation of the amount of fluid in the abdomen. Also we used transvaginal ultrasonography for calculating of the diameter of masses.

\section{Data collection tools}

Data was obtained from the patient files and hospital records.

\section{The ethical aspect of research}

The protocol was approved by the Ethics Committee of Faculty of Medicine of Gazi University (Approval date and number: December 3,2018;902).

\section{Statistical analysis}

SPSS software version 22.0 was used for statistical analysis variables. Descriptive statistics were used as categorical and continuous variables. Categorical variables were presented with number and percentage and continuous variables were presented as mean \pm standard deviation for normally distributed data and median (minimummaximum value) for non-normally distributed data. Student $t$ test and Mann-Whitney $U$ test was used for the comparison of variables whether they are normally distributed or not.

\section{Results}

The mean age of patients were 58.7 
(ranging from 34 up to 85 years old). 40 cases of 51 patients $(78.4 \%)$ were in menopausal period. The rate of the cases with nulliparous, primiparous and multiparous were respectively $7.8 \%, 13.7 \%$ and $78.4 \%$. The avarage diameter of tumours was 8.23 , ranging in size from $3 \mathrm{~cm}$ to $30 \mathrm{~cm}$. While the $54.8 \%$ of the tumours were right sided, $45.1 \%$ of them were left sided (Table 1). The most common presenting symptom was abdominal discomfort and pain $(41.2 \%)$. All specimens were reported as sexcord stromal tumor in frozen section. The distribution of the final pathological results were fibroma, fibrothecoma, celuler mitotic fibroma, and the rate of them were respectively $45.2 \%, 35.3 \%, 13.7 \%$. Thecoma, fibrothecoma with insitu serous carcinoma, fibroma with endometrial cyst were observed seperately in each patient. Ascite was detected in $6(11.7 \%)$ cases, and hydrothorax was detected in one of these cases as Meigs Syndrome. Ca-125 levels were high in 12 cases $(23.5 \%)$ and 3 of them had also incerased Ca19-9 (5.9\%) levels (Table 2 ). In these patients, one of them diagnosed final pathology results as synchronous uterine carcinosarcom with fibrothecoma and on the other hand Meigs Syndrome observed in one of them. $11(21.6 \%)$ patients underwent laparoscopy, and 40 (78.4\%) underwent laparotomy (Table 3). Unilateral salpingoopherectomy was performed in 10 $(19.6 \%)$ cases; $8(15.7 \%)$ patients of these cases were in premenopausal period and they had desire of preservation for fertility. $2(3.9 \%)$ other cases were $>74$ years old, the operation time had to be kept short because of their systemic diseases.

Table 1. Demographic characteristics of patients

\begin{tabular}{lc}
\hline Demographic features & n (mean \pm SD) (\%) \\
Age (min-max) & $58.7 \pm 11.2(34-85)$ \\
Nullipar & $4(7.8)$ \\
Primipar & $7(13.7)$ \\
Multipar & $40(78.4)$ \\
Menopause & $40(78.4)$ \\
Cyst diameter(min-max) & $8.2 \pm 4.8(3-30 \mathrm{~cm})$ \\
Localization & \\
Right sided & $28(54.9)$ \\
Left sided & $23(45.1)$ \\
Associated symptoms & \\
Asymptomatic & $20(39.2)$ \\
Menometrorrhagia & $2(3.9)$ \\
Postmenopausal bleeding & $8(15.7)$ \\
Abdominal discomfort pain & $21(41.2)$
\end{tabular}

Total 51

Table 2. Clinico-pathologic results of fibroma/fibrothecoma cases.

\begin{tabular}{lc}
\hline Clinico-pathologic results & n (\%) \\
\hline Final pathologic results & \\
Fibroma & $23(45.2)$ \\
Celular mitotic fibroma & $7(13.7)$ \\
Fibrothecoma & $18(35.3)$ \\
Thecoma & $1(2)$ \\
Fibroma+endometrial cyst & $1(2)$ \\
Fibrothecoma+insuti serous carcinoma & $1(2)$ \\
Clinic and laboratory results & \\
Associated with assit & $6(11.7)$ \\
Associated with Meigs Syndrome & $1(2)$ \\
High serum ca125 levels $(>35 \mathrm{U} / \mathrm{ml})$ & $12(23.5)$ \\
High serum ca19-9 levels $(>35 \mathrm{U} / \mathrm{ml})$ & $3(5.9)$ \\
Total & $\mathbf{5 1}$ \\
\hline
\end{tabular}

Table 3. Distribution of surgical methods in fibroma/fibrothecoma

\begin{tabular}{lc}
\hline Surgical method & n (\%) \\
Laparoscopy management & \\
L/S Unilateral salpingoopherectomy & $6(11.8)$ \\
TLH+BSO & $5(9.8)$ \\
Laparotomy management & \\
L/T Unilateral salpingoopherectomy & $4(7.8)$ \\
TAH+BSO & $34(66.7)$ \\
TAH+BSO+PPLND+Omentectomy & $2(3.9)$ \\
Total & $\mathbf{5 1}$ \\
\hline
\end{tabular}

Two cases $(3.9 \%)$ of them underwent total abdominal hysterectomy, bilateral salpingooophorectomy, omentectomy, pelvic and paraortic lymphadenectomy. One of these cases suffered from postmenopausal bleeding, an endometrial biopsy was done and preoperative uterine carcinosarcoma with adnexal mass was diagnosed. The final pathological result of this patient was fibrothecoma with uterine carcinosarcoma (Figure 1, 2). The other case suffered from postmenopausal bleeding too, an endometrial biopsy was done, and preoperative uterine endometrioid adenocancer with adnexal mass was diagnosed, and the final pathologic report was fibroma with endometrioid adenocancer (Figure 3, 4). One case whose final pathologic assesment was thecoma with endometrioid adenocancer was diagnosed preoperative by the endometrial biopsy and only total abdominal hysterectomy and bilateral salpingo-oophorectomy was performed because the histopathology result was grade 1 endometrioid type tumor and noninvasive to myometrium. 


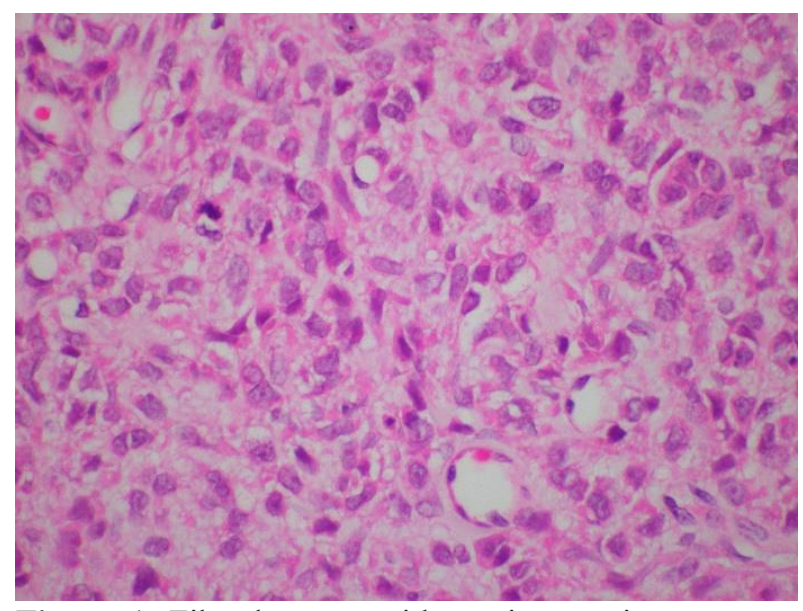

Figure 1. Fibrothecoma with uterine carcinosarcoma, H\&Ex600; hemotoxylin-eosin

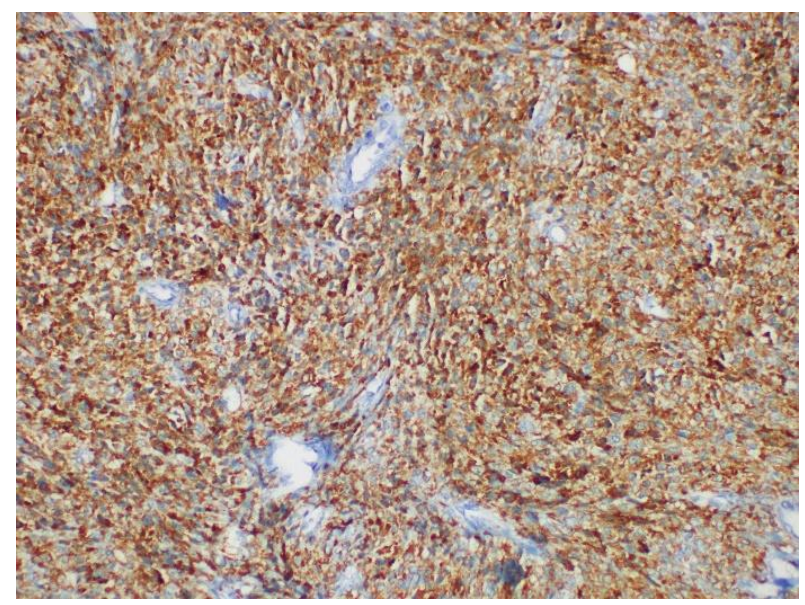

Figure 2. Fibrothecoma with uterine carcinosarcoma. IHCx200; Inhibin, immunohistochemistry

\section{Discussion}

Ovarian fibromas/fibrothecomas, benign tumors of the ovary, were classified in sex-cord stromal cell tumors as thecoma-fibroma group, corresponding to $1 \%$ to $4.7 \% .^{12}$ These tumors can be seen at any age, but they typically occur in the postmenopausal period. Also in some studies two peaks of frequency were reported; the first peak is postmenopause while the second is between 20 and 40 years. ${ }^{6}, 13$ In this present study, the patients' mean age was 58.7, and $78.4 \%$ of the cases were postmenopausal period, and the age distribution of the cases was similar to some studies. ${ }^{5}, 13,14$ whereas the age distribution was different from the other previous reports. ${ }^{8}, 9$

The incidence of multiple and bilateral ovarian fibroma/fibrothecoma is approximately $10 \% .{ }^{2},{ }^{15}$ However, in our series, all of them were localised unilateral and single which occured slightly more common $(54.8 \%)$ on the right side, which is different from the

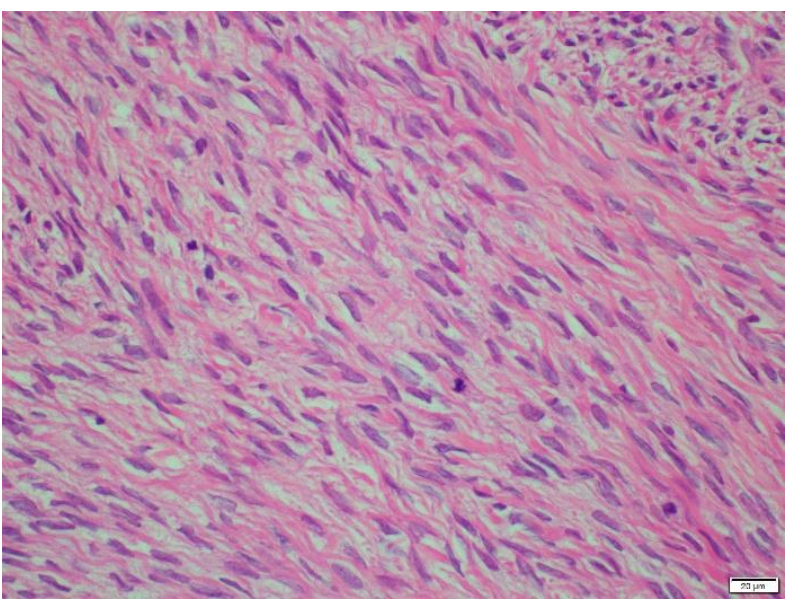

Figure 3. Thecoma with endometrioid adenocancer. H\&Ex400; hemotoxylin-eosin

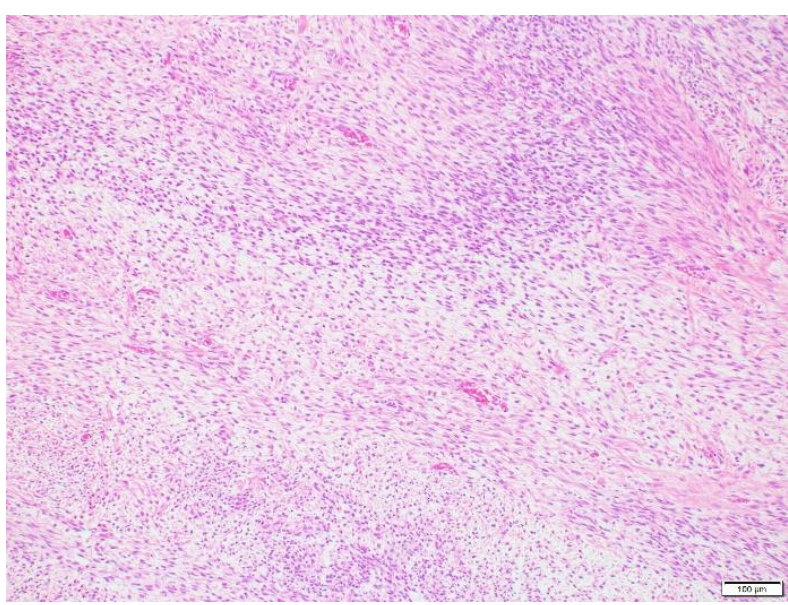

Figure 4. Thecoma with endometrioid adenocancer. H\&Ex100; hemotoxylin-eosin

other studies. $.^{4}, 13,14$

The histopathological assesment causes different types of sex-cord stromal tumors group, according to different types of characteristics of the predominant cells. The most common form of this group is ovarian fibroma. The tumor is characterized by the presence of spindle- shaped cells like fibroblasts. If the predominant cells are similar to theca cells, it is classified as ovarian thecoma. When fibroblast and thecoma cells are seen together, it is called fibrothecoma. ${ }^{13}$ The cells in the fibroma which are composed of closely packed nuclei with absent or minimal nuclear atypia and 1-3 mitoses/10 high-power fields are called cellular fibromas. ${ }^{15}$ If mitotic counts over 4 per 10 high power fields are consistent with the tumor, they are called mitotically active cellular fibroma. When fibroblastic tumors include modarate nuclear atypia and more than 3 mitoses/10 high-power fields, they frequently behave malignant and are accepted fibrosarcomas. ${ }^{16,17}$ 
The incidence of high cellularity, mitotic activity and nuclear atypia in fibromatous tumors are about $10 \% . .^{15}$ In this study, the histopathologic prevalence of 51 cases such as fibroma, fibrothecoma, celuler mitotic fibroma and thecoma and the rate of them are respectively $45.2 \%, 35.3 \%, 13.7 \%$ and $2 \%$. However, in our series, fibrosarcoma was not observed.

The size of ovarian fibromas are usually large at presentation. The mean diameter of the tumors in our series was 8.2 (range $3-30$ ) cm, larger than the previous studies reported. $.^{2}, 18$ The case of enormous tumors associated with ascites is usually an indicator of malignancy. Ascites can occur with the fluid secretion of tumor, It occurs when the tumor surface is large or as a result of mechanical irritation of peritoneal surface. Ovarian fibroma/fibrothecoma is associated with aproximately $10-15 \%$ of ascites and $1 \%$ Meigs Syndrome. Therefore, this clinical situation can be confused with malignancy. In $6(11.7 \%)$ cases, ascites was present in this study, which showed a consistency with the previous reports in the litreature. ${ }^{7},{ }^{19}$ The presence of ascites was associated with neither tumor size nor with the high level of ca125 (respectively, $p=0.802$, $p=0.134$ ) (Table 4). Cho YJ and et al, demostrated that the existence of ascites was associated with larger tumor size $(p=0.006)$, but not with higher ca-125 levels $(p=0.159) .{ }^{19}$

Table 4. Relationship of ascites with tumor size and Ca-125 levels.

\begin{tabular}{llll} 
& $\begin{array}{l}\text { Ascites absent } \\
(\mathbf{n}=\mathbf{4 5})\end{array}$ & $\begin{array}{l}\text { Ascites present } \\
(\mathbf{n}=6)\end{array}$ & $\boldsymbol{p}^{*}$ value \\
$\begin{array}{l}\mathbf{C a}-\mathbf{1 2 5} \geq \mathbf{3 5 I U} / \mathbf{m l} \\
(\mathbf{n}=\mathbf{1 2})\end{array}$ & $9(75 \%)$ & $3(25 \%)$ & 0.134 \\
$\begin{array}{l}\mathbf{C a}-\mathbf{1 2 5}<\mathbf{3 5 I U} / \mathbf{m l} \\
(\mathbf{n}=\mathbf{3 9})\end{array}$ & $36(92.5 \%)$ & $3(7.7 \%)$ & \\
Tumor size, $\mathbf{c m}$ & $7.0 \pm 5.0$ & $6.5 \pm 3.9$ & 0.802 \\
\hline
\end{tabular}

Meigs syndrome, first described by Meigs and Cassa in 1937. They reported benign ovarian tumor, ascites and hydrothorax. The ovarian tumors were fibroma, Brenner tumor, granulosa cell tumor. After the removal of ovarian tumor, fluid in the spaces disappeared. ${ }^{20}$ Meigs syndrome origined by ovarian fibroma/fibrothecoma, with high serum Ca-125level has been reported only in 32 cases in the published literature..$^{20-23}$ Meigs syndrome with elevated Ca-125 level was determined, the incident rate of only one case $(2 \%)$ in all of the cases was similar to the other studies. ${ }^{5,6}$ The other clinical association is called Gorlin-Goltz Syndrome or basal cell nevus syndrome, which is observed with ovarian fibroma/fibrothecoma although it was not observed in none of the patients in our series. Pelvic mass is usually determined at the routine physical examination without any obvious clinical symptomatic reasons among the most patients with ovarian fibroma/fibrothecoma. The symptomps are those such as; abdominal swelling, pain or discomfort, which are the results of the large size pelvic mass, and these are the most common reasons for the patient's admission to hospital. In our series, there were 20 asymptomatic patients $(39.7 \%)$ who applied forthe routine pelvic examination; however, the fibroma/fibrotechama was incidentally determined on these patients, the most frequent complaint was abdominal discomfort and pain $(41.2 \%)$, the rest of which were respectively; menometrorrhagia $(3.9 \%)$, postmenopausal bleeding (15.7\%). The rate of complaints about abdominal discomfort and pain in our series was similar to the other reports, and the average size of tumor was $11.7 \mathrm{~cm}$ in these patients. $^{3}$ Thecoma occurs only $0.5 \%$ to $1 \%$ of ovarian tumors, and it is rarely malignant, it may secrete estrogen, and it may lead to symptoms such as menstruel disorders and postmenoposal bleeding. ${ }^{24}$ One of the patients applied because of postmenopausal bleeding and approximately $10 \mathrm{~cm}$ diameter ovarian cyst was incidentally determined during the pelvic examination. Endometrial biopsy was performed, and endometriod type grade 1 cancer was diagnosed in this patient. In this study, $15.9 \%$ of the cases had a higher role of admission with postmenopausal bleeding unlike the other reports. ${ }^{5}$ In our series, most of the the patients were in postmenopausal 
period, and that's why the rate of postmenopausal bleeding was high.

The origin of serum $\mathrm{Ca}-125$ with the cases of ovarian fibroma/fibrothecoma remains obscure. Some previous reports have demonstrated that the source of elevated serum ca-125 level is not because of tumor cells, but because of some factors such as a mechanical irritation of peritoneum or an increase intraperitoneal pressure from large size of tumor and ascites. High serum levels of tumor markers such as Ca-125, Ca-19-9 with ovarian fibroma/fibrothecoma can be observed occasionally, and regress after the removal of the tumor. ${ }^{25}$ In this study, $23.5 \%(12 / 51)$ of the patients had ca-125 levels $\geq 35 \mathrm{IU} / \mathrm{ml}$ and their average tumor size was $11.5 \mathrm{~cm}$ (Table 4). Ten $(83.3 \%)$ patients with the high Ca-125 levels were in postmenopausal period, and two of them were in premenopausal period. These results are similar to the other studies. ${ }^{14}$ The presence of high serum ca-125 level was associated with larger tumor size $(p=0.01)$, but not with existence of ascites $(p=0.134)$ (Table $5)$.

Table 5. Relationship of Ca-125 levels with tumor size.

\begin{tabular}{llll}
\hline & Ca-125 $\geq \mathbf{3 5 I U} / \mathbf{m l}$ & $\mathbf{C a}-\mathbf{1 2 5}<\mathbf{3 5 I U} / \mathbf{m l}$ & $\boldsymbol{p}^{*}$ value \\
Tumor size,cm & $10.0 \pm 6.8$ & $6.0 \pm 3.6$ & 0.010 \\
\hline
\end{tabular}

Mann-Whitney U test*

The risk of malignancies in solid ovarian tumors forced surgeons for the diagnosis which can only be defined by histological assessment. Therefore, surgery is the choice of treatment and diagnosis for solid tumors, like fibroma/fibrothecoma. The treatment methods of surgery is decided according to the size of tumor, age of the patient, desire to preserve fertility and presumptive preoperative diagnosis. For the patients in reproductive period, conservative or fertility preserve surgery by unilateral salpingo-oophorectomy or the ovarian cystectomy is performed. An aggressive radical surgery by total abdominal hysterectomy and bilateral salpingooopherectomy should be considered in postmenopausal period. Thanks to the accurate diagnosis in preoperative period and especially if the tumor size is relatively small, the laparoscopic management can be performed succesfully. ${ }^{9-11,13,19}$

The presence of large size tumor, high ca125 levels and ascites are caused the suspicison of malignancy. Therefore, invasive surgery was performed instead of laparoscopic surgery. In our series, because of these findings the surgery approach was applied to $21.6 \%$ of cases by laparoscopy whereas the surgery approach was applied $78.4 \%$ of them by laparotomy.

\section{Conclusion}

Ovarian fibroma/fibrothecomas are uncommon, benign solid tumors that are detected frequently in postmenopausal period. There are diagnosed difficulties because their sonographic findings are similar to uterine myoma and they are often mistaken with malignant ovarian tumor as they are associated with high serum Ca-125 levels and ascites. The frozen section examination in the operative room helps surgeon for deciding the extent of surgery. Fertility preserving surgery for reproductive period and total abdominal hysterectomy and bilateral salpingoopherectomy in menopausal period is the current standard treatment via laparoscopy or laparotomy.

\section{Ethics Committee Approval}

The protocol was approved by the Ethics Committee of Gazi University' Faculty of Medicine (Approval date and number: December 3,2018;902).

\section{Informed Consent}

Informed consent forms were obtained from all participants.

\section{Authors' Contributions}

Conception-F.K., M.A.O.; Design-F.K., M.A.O., M.A.I.; Supervision-F.K., M.A.O., Ö.E.; Materials- M.A.O., Ö.E.; Data Collection and/or Processing-F.K., M.A.İ., N.Y.; Analysis and/or Interpretation-M.A.O., Ö.E., N.Y.; Literature review- M.A.O., Ö.E., N.Y; Writer-F.K., Ö.E., N.Y.; Critical ReviewF.K., N.Y. 


\section{Conflict of Interest}

No conflict of interest was declared by the authors.

\section{Financial Disclosure}

The authors declared that this study has received no financial support.

\section{Peer-review}

\section{Externally peer-reviewed}

\section{References}

1 Numanoglu C, Kuru O, Sakinci M, et al. Ovarian fibroma/fibrothecoma: retrospective cohort study shows limited value of risk of malignancy index score. Aust $N \mathrm{Z} \mathrm{J}$ Obstet Gynaecol. 2013;53(3):287-292.

2 Sivanesaratnam V, Dutta R, Jayalakshmi P. Ovarian fibromaclinical and histopathological characteristics. Int $J$ Gynaecol Obstet. 1990;33(3):243-247.

3 Sfar E, Ben Ammar K, Mahjoub S, et al.Anatomo-clinical characteristics of ovarian fibrothecal tumors. 19 cases over 12 years:1981-1992. Rev Fr Gynecol Obstet 1994; 89:315-321.

4 Gargano G, De Lena M, Zito F, et al. Ovarian fibroma: our experience of 34 cases. Eur J Gynaecol Oncol 2003; 24: 429432.

5 Paladini D, Testa A, Van Holsbeke C, et al. Imaging in gynecological disease (5): clinical and ultrasound characteristics in fibroma and fibrothecoma of the ovary. Ultrasound Obstet Gynecol. 2009;34(2):188-195.

6 Genc M, Solak A, Genc B, et al. A diagnostic dilemma for solid ovarian masses: the clinical and radiological aspects with differential diagnosis of 23 cases. Eur J Gynaecol Oncol.2015;36(2):186-191.

7 Chen H, Liu Y, Shen LF, et al. Ovarian thecoma-fibroma groups: clinical and sonographic features with pathological comparison. J Ovarian Res 2016;9:81.

8 Chechia A, Attia L, Temime RB, et al. Incidence, clinical analysis, and management of ovarian fibromas and fibrothecomas. Am J Obstet Gynecol 2008; 199: 473.e1-e4.

9 Cho YJ, Lee HS, Kim JM, et al. Clinical characteristics and surgical management options for ovarian fibroma/fibrothecoma: a study of 97 cases. Gynecol Obstet Invest. 2013;76:182-7.

10 Jung $\mathrm{NH}$, Kim $\mathrm{T}$, Kim HJ, et al. Ovarian sclerosing stromal tumor presenting as Meigs' syndrome with elevated CA-125. J Obstet Gynaecol Res 2006;32:619-22.

11 Son CE, Choi JS, Lee JH, et al.Laparoscopic surgical management and clinical characteristics of ovarian fibromas. JSLS 2011; 15: 16-20.

12 Târcoveanu E, Dimofte G, Niculescu D, et al. Ovarian fibroma in the era of laparoscopic surgery: a general surgeon's experience. Acta Chir Belg 2007; 107: 664-669.

13 Tinelli A, Pellegrino M, Malvasi A, et al. Laparoscopical management ovarian early sex cord-stromal tumors in postmenopausal women: a proposal method. Arch Gynecol Obstet 2011; 283(suppl 1):87-91.

14 Kurman RJ, Carcangiu ML, Herrington S, et al. World Health Organization Classification of Tumours of the Female Reproductive Organs. IARC, Lyon, 2014. Copyright (C) 2014.

15 Leung SW, Yuen PM. Ovarian fibroma: A review on the clinical characteristics, diagnostic difficulties, and management options of 23 cases. Gynecol Obstet Invest 2006;62:1-6

16 Parwate NS, Patel SM, Arora R. Ovarian Fibroma: A clinicopathological study of 23 cases with review of literatüre. J Obstet \& Gynecol Indina.2016; 66(6):460-465.

17 Prat J, Scully RE: Cellular fibromas and fibrosarcomas of the ovary: a comparative clinicopathologic analysis of seventeen cases. Cancer 1981; 47: 2663-2670.

18 Irving JA, Alkushi A, Young RH, Clement PB. Cellular fibromas of the ovary: a study of 75 cases including 40 mitotically active tumors emphasizing their distinction from fibrosarcoma. $\mathrm{Am} \mathrm{J}$ Surg Pathol 2006; 30: 928-38.
19 Young RH. Ovarian sex cord-stromal tumours and their mimics. Pathology: 2018;50(1):5-15

20 Dockerty MB, Masson JC: Ovarian fi bromas: a clinical and pathologic study of 283 cases. Am J Obstet Gynecol 1944; 47: 741.

21 Cha MY, Roh HJ, You SK, et al. Meigs' syndrome with elevated serum CA 125 level in a case of ovarian fibrothecoma. Eur $J$ Gynaecol Oncol 2014;35:734-737

22 Sofoudis C, Kouiroukidou P, Louis K, et al. Enormous ovarian fibroma with elevated Ca-125 associated with Meigs' syndrome. Presentation of a rare case. Eur J Gynaecol Oncol 2016;37:142143.

23 Chan WY, Chang CY, Yuan CC, et al. Correlation of ovarian fibroma with elevated serum CA-125. Taiwan J Obstet Gynecol 2014;53:95-96.

24 Young RH. Thecoma of the ovary: a report of 70 cases emphasizing aspects of its histopathology different from those often portrayed and its differential diagnosis. Am J Surg Pathol. 2014;38(8):1023-1032.

25 Renaud MC, Plante M, Roy M. Ovarian thecoma associated with a large quantity of ascites and elevated serum CA 125 and CA 15-3. J Obstet Gynecol Can 2002;24:963-965. 